\title{
Evolution in the Science Curriculum: The Need for a Middle Ground
}

\author{
Brandon S. Diamond ${ }^{1}$ \\ ${ }^{1}$ Department of Biology, University of Miami \\ Correspondence: Brandon S. Diamond, Department of Biology, University of Miami, 1301 Memorial Dr., Coral Gables, \\ FL 33146, USA
}

Received: July 13, 2014 Accepted: July 25, 2014 Online Published: August 14, 2014

doi:10.11114/jets.v2i4.488

URL:http://dx.doi.org/10.11114/jets.v2i4.488

\begin{abstract}
Debates over the teaching of evolution and creationism in schools abound, and very few people seem to actually know the arguments of the opposing viewpoint. Perhaps more importantly, the debate is generally waged between members with extreme views on each side, while the silent majority holds views that are more moderate. This paper describes the various belief systems that come into play in this debate, concentrating on the various forms of Judeo-Christian creationism and the theory of evolution. The paper then goes on to describe the history of the debate itself, including laws that have been passed in response to this debate, and the effects the debate is having on the way evolution is (or is not) being taught in schools. The conclusion discusses how the ideas of evolution and creationism do not have to be mutually exclusive, but that there is a proper time and place to teach each viewpoint.
\end{abstract}

Keywords: Evolution, Creationism, Science Education, Religion, Intelligent Design, Controversy, Curriculum

\section{Introduction}

One of the biggest debates in biology curricula today, and over the past century, is whether, and how, evolution should be taught in schools. The controversy comes from the many different groups involved, each with their own opinions on the matter. Unfortunately, very few of these groups take the time to find out why the other side believes as they do, making it difficult to reach an understanding, in turn making it even more difficult to decide what to teach in school science.

The purpose of this paper is not to change how members of the two extremes of the debate view each other's beliefs. Instead, the paper makes the case that the majority of Americans, along with the majority of Western society, including many scientists, actually believe something towards the middle, and these moderate beliefs are the ones not being represented in the debate. Most of the debate occurs between the vocal minorities on either side, with each side trying to win a complete victory. If the silent majority, who believe in a compromise position between the two stances, becomes vocal, evolution can continue to be taught in public schools and religious views can continue to be taught in religious settings, so that both views are learned and respected.

Many papers exist that attempt to convince the reader that one side of the debate is correct and the other side has no place in any educational setting. These papers are usually written by a vocal minority whose opinions do not represent the majority opinion of the community they claim to represent. This paper is an argument for the need for a middle ground, where both sides of the debate can reach an agreement of what is appropriate to teach, and when. Sections 2 and 3 of this paper presents a brief overview of the foundational beliefs of creationism and evolution, along with some examples of worldviews that incorporate the two. Section 4 discusses how the debate is affecting science education, both legally and in the classroom, and what is being recommended to bring an understanding of evolution to a majority of students. Finally, the conclusion explains why the rarely discussed middle ground must be found for the debate to be resolved.

\section{The Foundational Beliefs of Creationism and Evolutionism}

\subsection{Judeo-Christian Creationism}

God created the great sea monsters, and all the living creatures of every kind that creep....and all the winged birds of every kind.... God made wild beasts of every kind and cattle of every kind, and all kinds of creeping things on the earth....And God created man in His image. (Genesis 1:21-27 Jewish Publication Society) 
The Lord God said, "It is not good for man to be alone; I will make a fitting helper for him." And the Lord God formed out of the earth all the wild beasts and all the birds of the sky. (Genesis 2:18-19)

When taken literally, the above, seemingly contradictory, Bible verses are the centerpiece of the Western Creationist movement. Special creation is the doctrine that each species was created independently by God in its present form (Futuyma, 2009; Scott, 2004). There are several different types of creationism, varying primarily by how literally supporters interpret Genesis (Scott, 2004). Flat Earthism is the belief that the Bible always takes priority over science, including the continuing belief that the Earth is flat, despite evidence to the contrary. "Geocentrists accept that the earth is a sphere, but deny that the sun is the center of the solar system" (Scott, 2004, p. 58). Young Earth creationism accepts the scientific views of the shape and position of the Earth, but contends the earth is at most 15,000 years old, but probably closer to 6,000. All three of these views reject many scientific explanations for phenomena, including evolution and all its related concepts. It should be noted that, as with all belief systems, the beliefs of individual members or groups of these Creationist systems often vary.

The next four belief systems are called Old Earth creationism, a group of beliefs that accept most of science, but have differences in opinion about evolution (Scott, 2004). Gap creationism states there was a large temporal gap between the first day of creation and the other six; the Earth itself is old, but everything on it was created in six days. Day-Age creationism says each of the six days of creation was actually a much longer period of time. Progressive creationism believes the Big Bang is proof of the initial creation out of nothing, but all organisms that have ever existed lived simultaneously at the beginning. Evolutionary creationism believes God continually uses evolution to shape the universe. This is the most liberal of Creationist stances, but it is still primarily a religious belief rather than a scientific theory. When the various forms of evolutionism are described, theistic evolution will be shown to be on the other side of this fine line.

\subsubsection{Creationism as Science}

An early attempt to make creationism look scientific so it would be taught in public schools was creation science (Futuyma, 2009). It attempted to use science to disprove the theory of evolution, but no actual science was used by its supporters. As each incarnation of creation science has been struck down as unconstitutional (section 4.1), a new, less aggressively religious version has risen up to take its place. The most successful version of creation science is probably Intelligent Design (ID).

According to the Discovery Institute "The theory of ID holds that certain features of the universe and of living things are best explained by an intelligent cause, not an undirected process such as natural selection" (Center for Science \& Culture, 2011). The Institute goes on to say they would prefer that schools teach the strengths and weaknesses of evolution, rather than force schools to teach ID. The Discovery Institute's website, www.intelligentdesign.org, has almost 70 links to websites that "disprove" the validity of Darwin's theory by such scientific research as blogging. Four of these sites are labeled as "state-based organizations:" Science Excellence for all Ohioans, ID Network of Ohio, ID Network New Mexico Division, and Texans for Better Science Education. None of these sites are actually run by a state government.

Critics of ID call it a repackaging of creationism (Radder, 2006). ID is very careful to rely on scientific language to describe non-scientific concepts. The concepts are non-scientific because they do not publish in peer-reviewed science journals and the hypotheses cannot be studied by experiment and the study of evidence. They use the language of liberalism, (e.g., balance, teach all sides) and compare their goals to those of Martin Luther King, Jr. to make the ideas less obviously conservative and more difficult to refute on moral grounds (Apple, 2008).

\subsection{The Theory of Evolution}

Futuyma (2009) defines biological evolution as "change in the properties of groups of organisms over the course of generations" (p. 2). Charles Darwin famously published this concept in his 1859 490-page "abstract" On the origin of species by means of natural selection, or the preservation of favoured races in the struggle for life. Partially due to nervousness about the backlash he expected from his findings, Darwin did not publish until he had 20 years' worth of data and a colleague ready to make the same claims. Darwin's theory consisted of five parts: evolution is change over time, all species diverged from common ancestors, evolution occurs gradually, the changes in populations are in the proportions of inherited traits, and natural selection occurs when adaptations allow certain individuals to survive and reproduce.

The evolutionary synthesis of the 1940's was the next major step in the development of the theory of evolution (Futuyma, 2009). A world renowned group of geneticists, systematists, and paleontologists reconciled Darwin's theory with the more newly discovered facts of genetics. They also showed that some of Darwin's alternative mechanisms worked together to cause the overall process of evolution. Since the discovery of DNA's structure in 1953, evolutionary 
research has often concentrated on using genetics and molecular biology to explain evolutionary processes and to estimate evolutionary relationships between species.

Modern evolutionary theory is therefore best explained using genetic principles. For evolution to occur, phenotypic variation (i.e., differences in the actual physical characteristics of the members of a species caused by the genes of the individuals) must be present. Without variation, there is no mechanism for change. Evolution occurs when the proportions of alleles, or types of a specific gene, change. It does not occur in individuals, contrary to popular misconceptions. When the proportions of alleles change, the likelihood of specific phenotypes showing up in the next generation also changes.

There are several mechanisms for changing allele frequencies. The mechanism that Darwin spent most of his time explaining, and the best known mechanism, is natural selection, also known as survival of the fittest. Darwin's definition of fitness was surviving long enough to produce offspring, thereby passing on one's traits (i.e., alleles). Any trait that allows an organism to catch prey or avoid becoming prey, or otherwise allows the organism to more successfully reproduce, is called an adaptation. Organisms with the adaptations best suited for a specific environment will be most likely to mate and reproduce. Organisms that die before reproducing take their alleles with them, thereby decreasing their frequency in the population. If members of a species end up in two very different environments with no way to reconnect, each group will undergo different natural selection, and may eventually become different species.

There are other mechanisms for evolution that are less well known by the public, but just as important. The most important of these is mutation, the process by which an allele changes into a different allele. Without mutation, there cannot be the genetic variation that is required for evolution to occur. Mutations are usually harmful or negligible, but they are occasionally beneficial. In genetic drift, random chance (e.g., caused by natural disasters) kills some individuals but not others, leading to a change in allele frequencies in the population. Gene flow, or migration, is when individuals permanently leave or enter a population, bringing their alleles with them. The final mechanism, nonrandom mating, is often caused by pairs of individuals that are closely related or have similar alleles mating. This can cause traits that would otherwise be rare in the population to become much more common.

\section{Current Beliefs about Evolution}

\subsection{Religious Beliefs}

In 1990, about $86 \%$ of Americans identified themselves as Christian (Scott, 2004). In 2001, that number had declined to $76.5 \%$, and the number of people who believed in God declined from $89.5 \%$ to $80.2 \%$. Antievolutionism movements (section 2.1.1) are most often found among conservative Christian groups, explaining why they are well known in the United States (U.S.). It is more rarely found in Islamic or Jewish countries in the Middle East (Scott, 2004), and not all Christians agree with it, either. It can therefore be inferred that belief in God and in evolutionary theory are not mutually exclusive. The position of the Catholic Church and most mainstream Protestant seminaries is that of Theistic Evolution, which accepts most of modern science, but also allows for God to use the laws of nature to intervene when necessary (Miller, Scott, \& Okamoto, 2006; Scott, 2004). In fact, nine of the twelve largest Christian denominations have actively supported evolution (Matsumura, 1998). The former Evangelical Christian director of the National Institutes of Health is an example of a biologist who actively tries to convince Christians that evolution is an explanation of God's work, rather than being contradictory to the idea of $\mathrm{God}(\mathrm{Vu}, 2011)$.

While many evolutionists believe in God, some do not. Agnostic Evolutionists argue that the existence of God cannot be proven or disproven; therefore belief should be suspended until proof can be found (Scott, 2004). This may seem at first to be the same as claiming that religion is not science and therefore cannot be addressed by science, except that a judgment is being made: belief should be suspended. The most extreme group on this side of the spectrum is the Materialist Evolutionists, who believe that the supernatural does not exist, so there is no God. This group includes atheists, who tend to be actively antireligious. Humanists, who are often agnostic or atheist, believe that humans have a responsibility to lead meaningful, ethical lives without supernatural reasons.

It is the atheist scientists that tend to write in ways that antagonize religious people, both scientists and otherwise. Richard Dawkins, Chair of Public Understanding of Science at Oxford University, points out that Earth's age of 6000 years is incompatible with biological and geological evidence to begin his argument in favor of evolution (Dawkins, 1996). He goes on to admit that God's role in evolution cannot be disproven, but that these views of guided evolution assume organized complexity, which evolutionary theory attempts to explain. The problem with religion is that it does not explain the origin of the complexity based on evidence. If Dawkins had stopped there, his book would have been much less antagonistic to the many religious people, but he finishes his book by concluding that the only logical choice is to reject creationism and religion in general. It is this type of extremism on both sides that has led to the evolution debate. 


\subsection{Public Opinion}

A comparison conducted by Miller, Scott, and Okamoto (2006) between a 1985 survey and a 2005 survey found that the number of randomly sampled U.S. adults ( $\mathrm{n}>1400)$ that accepted evolution decreased from $45 \%$ to $40 \%$ and the number that rejected evolution decreased from $48 \%$ to $39 \%$. The increase was in the unsure adults, which went from $7 \%$ to $21 \%$. Significantly more adults accepted evolution in Japan and 32 European countries than in the U.S. "In Iceland, Denmark, Sweden, and France, $80 \%$ or more of adults accepted the concept of evolution, as did $78 \%$ of Japanese adults" (Miller et al., 2006, p. 765). Miller et al. found that more conservative Christian religious beliefs made a person more likely to reject evolution.

Predictive factors show what countries are less likely to accept evolution on average. In addition to fundamentalist religious beliefs, another indicator is the existence of a political party that holds antievolutionist platforms (e.g. the current Republican Party), although it is difficult to assign cause and effect. In the U.S., being pro-life (a conservative political stance) makes one significantly more likely to be antievolutionist. Countries with low frequencies of evolution rejection (e.g., Denmark, Iceland, Japan, and Sweden) do not have political parties that advocate against teaching it in schools. The third indicator is genetic literacy, where people who understand genetics are more likely to accept evolution; therefore countries in which it is taught are more likely to have citizens who believe in it. Many Americans do not understand modern biological concepts, including genetics, demonstrating another source of U.S. controversy.

\subsection{The Need for a Middle Ground in the Public Discourse}

Because of people like Dawkins, who treat science as proof that there is no God, some researchers have pointed out that some scientists treat evolution as a secular religion (Apple, 2008). The argument is not that the majority of evolutionary theory is untrue, but that scientists sometimes get overenthusiastic in their claims when arguing against creationism. If religious and nonreligious scientists get together to present a united front to the public, they could more easily persuade people that they do not have to choose between believing in religion or evolution. This united front would be a stance that says evolution is a scientific fact that does not deny the existence of God, a stance that many scientists and religious leaders already believe.

Both scientists and religious leaders are already working towards reconciliation. Jim Wallis, a well-known evangelical, argued "that there is little in the Bible that supports some of the extreme economic, political, and cultural positions currently advocated by ultra-conservatives within the evangelical movements" (Apple, 2008, p. 334). Robert Pollack (2005), a biologist and the Director of the Columbia Center for the Study of Science and Religion, argues that a distinction should be made between scientific religion and religious science. He argues that while it is futile to try to pin religious meaning to the amoral mechanism of natural selection, it is reasonable to turn to religion to understand moral issues that touch upon science. Science decides whether we could clone a person, and religion (or morals for humanists) dictates whether we should clone a person. Therefore, science and religion can coexist. If more religious leaders and scientists are willing to meet in the middle like this, the controversy may decrease substantially. Once the public discourse moves away from the idea of a choice between science and religion, and toward a discussion of how to best incorporate each subject into our lives, the debate surrounding the teaching of evolution in public schools can also begin to be resolved.

\section{The Intersection of Evolutionary Beliefs and School Science Curriculum}

The evolution vs. creationism debate has long been, primarily between the vocal extremists on both ends of the spectrum, with those in the middle trying to compromise. In 1925, Nature published a letter attributing the debate to the tendency of both secular and religious teachers teaching their views enthusiastically and pouring equal amounts of scorn upon the other (Lodge, 1925). The same writer went on to argue a theistic evolution worldview:

My thesis is that there is no essential opposition between creation and evolution. One is the method of the other. They are not two processes, they are one - a gradual one which can be partially and reverently followed by the human mind. We have the right to study the methods so far as we can... without the least trace of impiety, and without being reasonably accused of denying a great tract of country... which we are not exploring. (p. 940)

\subsection{U.S. Law}

Evolution in the curriculum became a legal matter in the U.S. in January of 1925 (The scopes 'monkey' trial and the separation of church and state, vol. 3: 1920-1929, 2001). The Tennessee General Assembly passed a law forbidding the teaching of Darwin's theory of evolution in public schools. High school science teacher John Scopes, with the support of the American Civil Liberties Union (ACLU), taught Darwin's theory anyway, and was soon arrested. The ACLU retained some of the country's top lawyers to defend John Scopes, who was found guilty. However, the ACLU was considered to have won in the court of public opinion, and the law forbidding the teaching of Darwin's theory ceased to be enforced until it was repealed in the 1970s. In fact, several other states also enacted similar laws in the 1920s, and 
those states also usually did not enforce them. It was the Scopes trial, though, that brought the controversy of whether to teach evolution in public schools to the American public discourse for the first time.

The issue of evolution in public schools first made it to the U.S. Supreme Court several decades later (Peters, 2008b). The state of Arkansas passed a law forbidding the teaching of evolution in public schools. Susan Epperson, an Arkansas biology teacher, sued the state for the right to teach evolution in her classes as a freedom of speech matter. Arkansas's Chancery Court agreed with Epperson, but the state Supreme Court upheld the law forbidding the teaching of evolution. In October of 1968, the U.S. Supreme Court heard the case Epperson v. Arkansas, and struck down the Arkansas law, citing the Establishment Clause, a prohibition of public schools advocating a particular religious view.

In 1986, the issue was brought to the U.S. Supreme Court again in Edwards v. Aguillard (Peters, 2008a). In 1981, Louisiana mandated that teachers spend equal time teaching evolution and creationism. The ACLU immediately fought the law in court, citing Epperson v. Arkansas as the precedent. In 1987, the Louisiana law was found to be in violation of the First Amendment, and was struck down.

Some famous legal arguments never went to the U.S. Supreme Court. In 1982, a U.S. District Court in Arkansas ruled that it is unconstitutional to require that creationism be taught in public schools, because it is not scientific (Borenstein, 2008). In 2005, a Dover, PA U.S. District Court Judge, John E. Jones III (a religious conservative), ruled that the school board could not encourage students to read about ID, because it is not science but thinly disguised religious doctrine (Futuyma, 2009). In his ruling, Jones made a statement that underlines the difference between arguing for religion and arguing against evolution:

Both Defendants and many of the leading proponents of ID make a bedrock assumption which is utterly false. Their presupposition is that evolutionary theory is antithetical to a belief in the existence of a supreme being and to religion in general. Repeatedly in this trial, Plaintiffs' scientific experts testified that the theory of evolution represents good science, is overwhelmingly accepted by the scientific community, and that it in no way conflicts with, nor does it deny, the existence of a divine creator. (Kitzmiller \& Dover Area School District et al, 2005)

\subsection{Creationists' Arguments for Teaching Alternatives to Evolution}

Creationists have two primary arguments in support of teaching ID in public school science classes (Borenstein, 2008). First, teaching evolution as undisputed can infringe upon a student's religious beliefs. Second, evolution has not been strongly scientifically proven. There are even some biologists who have taken an unusually anti-evolution stance. Michael Behe, Professor of Biochemistry at Lehigh University, is one of the founders of the aforementioned Discovery Institute. In his book Darwin's Black Box (1996), Behe argues through biochemistry that biology and evolution cannot explain the origins of many biological processes, thus advocating his concept of ID. Michael Denton (1985), an Australian medical doctor and scientist, argues that while Darwin was partially correct, biologists often treat as infallible his flawed theory. He further argues that homology fails to explain evolution, because homologous structures are arrived at via different routes via different genes, and he argues against chance as a mechanism because it is inefficient and incapable of achieving the "perfection" of life. This perfection, Denton argues, suggests the need for a designer.

Many students' beliefs, such as those of theistic evolutionists, agnostic evolutionists, and materialist evolutionists, would disagree with those of creationism. Even students who believe in creationism would want their specific view of how creationism works to be the one taught, and the many versions of creationism would make a consensus difficult to reach for public school purposes. Unlike the wide variety of creationist views, the overall theory of evolution has been very strongly supported by scientific evidence that is accepted by most biologists.

\subsection{Scientists' Arguments for Teaching Evolution as Scientific Fact}

The primary argument against teaching creationism in the classroom is not whether it should be taught, but whether it should be taught as science (Futuyma, 2009). For something to be considered science, it must start with a hypothesis that has failed to be disproven. Unlike other ways of knowing, it relies on the natural world as arbiter of truth (Scott, 2004). Science does not claim that it is infallible, and if new evidence emerges, it can change (Futuyma, 2009). In fact, scientists rarely use the word "proof," because it implies too much certainty (Scott, 2004). Since creationism is outside the abilities of science to test, it is not considered science. Science does not speak for or against the existence of God...it does not address the issue at all.

The word that is most often used incorrectly by creationists in regard to science is "theory." A scientific theory is a big idea that encompasses other ideas and hypotheses and combines them to make sense of natural phenomena (Borenstein, 2008; Futuyma, 2009; Scott, 2004). An idea has to be strongly supported by numerous tests to become a theory. In fact, scientists usually consider theories more important than facts or laws in terms of explanatory power (Scott, 2004). Creationists often call evolution "just a theory," as if it is not well supported. They also call their scientifically 
unsupported ideas theories, in an attempt to put them on equal ground with evolution. Some evolutionists, such as Futuyma (2009), argue that evolution has been so well tested and supported that it should be called a fact explained by a theory. While biologists do not claim to understand all of the details about how evolution works, they do claim that there is enough evidence to remove significant doubt about the existence of the overall process (Radder, 2006), and there is currently no debate in the peer-reviewed biological community about whether evolution has taken and is taking place (Borenstein, 2008). Any debates that occur are about details, not the overall process.

A common misconception about evolution is that it is impossible to observe, but in species with short generation times, microevolution is very easy to observe. Bacteria such as Staphylococcus aureus and Neisseria gonorrheae used to be easy to kill with antibiotics, but have evolved the ability to resist them since the 1940s (Futuyma, 2009). Viruses also evolve quickly, which is why AIDS patients must take three different drugs at a time to keep HIV under control. Another common misconception is that evolution is about the origin of living things, as opposed to changes in living things over time (Borenstein, 2008). The first appearance of life is a completely different subject, not included in evolutionary theory. Making this fact better known may help religious people reconcile their beliefs in the Bible with evolutionary theory, because the first appearance of life is one of the most important points to many religious activists.

\subsection{Public Opinion}

A Harris poll in 2005 in the U.S. showed that 55\% of surveyed adults thought children should be taught creationism/ID along with evolution in public schools (Radder, 2006). Fifty-four percent of respondents did not think humans evolved from an earlier ape-like species, a 9\% increase from a decade earlier. A National Science Teachers' Association poll in the same year showed that a third of the surveyed teachers felt pressure from parents and students to include ID and creationism in their science classes and/or omit evolution from their curriculum.

A 2008 poll of collegiate biology and biological anthropology faculty that taught evolution in Texas showed that 100\% of the 54 responders strongly supported teaching evolution without creationism or ID (Smith \& Eve, 2009). Ninety-one percent of 55 responders said that religious faith is compatible with acceptance of evolutionary biology, and about half of the responders described themselves as religious to some extent. These numbers show that while biology professors usually believe that creationism should not be taught in schools, most of them also believe that evolution and religion are compatible. About $85 \%$ of the respondents reported that students should arrive at college better prepared than they are in the subjects of evolutionary theory and evolutionary mechanism. The only topics reported as more lacking were English/Writing, Logic/Thinking, and Scientific Method, which are all much more general topics, and therefore more likely to be covered differently in various high schools than is evolution.

\subsection{Controversies in Science Education}

\subsubsection{Controversy in U.S. Science Education}

Controversies in science disciplines and controversies in science education vary greatly from each other. Unlike science disciplines, science education does not have a set of widely accepted procedures for dealing with controversy (Hildebrand, Bilica, \& Capps, 2008). While scientific controversy originates in the scientific community, science education controversy usually originates with parents, community members, and administrators with little scientific or educational research background. Scientific controversies are usually caused by new data, while science education controversies usually grow out of non-scientific considerations. Perhaps the most important difference is that scientific controversies can be settled by experimentation, while science education controversies involve so many social factors that they are difficult to even define, let alone resolve.

Just before the 1925 Scopes "Monkey" trial, John Dewey wrote that the establishment of the public's right to vote on issues did not necessarily allow them to discriminate between scientific and unscientific arguments (Hildebrand, Bilica, \& Capps, 2008). In other words, people are often asked to vote on matters they do not understand well. The most common solutions to the dilemma of how to deal with the controversy of teaching evolution are to "teach the controversy" (section 2.1.1), avoidance, where the topic is not taught, and dogmatism, where the controversy is ignored as not deserving notice. It is also damaging to tell students they do not have to believe in evolution. Hildebrand et al. argue that the various factions in the controversy need to sit down and establish common goals before trying to resolve their differences. They argue that by defining words like "truth" and acknowledging that a controversy does exist (in education, not in the science), steps can be taken to find a solution that would make everyone happy.

The controversy does not exist in a vacuum. The conservative journal Human Events released a list of the most harmful books of the $19^{\text {th }}$ and $20^{\text {th }}$ century (Apple, 2008; The ten most harmful books of the 19th and 20th centuries, 2005). While the top ten was occupied by such books as The Communist Manifesto and Mein Kampf, it also included books such as John Dewey's Democracy and Education. While they did not make the top ten list, Charles Darwin's two most famous books, Origin of Species and Descent of Man were on the list of books to avoid. The full list is too long to list 
here, but any book instrumental in fighting for advancement in science or in fighting class, gender, and racial inequity was on the list of "bad" books.

There is not a single isolated group that holds antievolutionary beliefs. This worldview has been found in the general public, high school students, undergraduate students, undergraduate biology majors, medical students, and science teachers (Nehm \& Schonfeld, 2007). Although knowledge and belief about a particular topic had been previously shown to only sometimes be correlated in other biology domains, Nehm and Schonfeld studied biology teachers who preferred not to teach evolution. After an evolution course, there was a significant increase in teacher understanding of the theory of evolution, yet almost no change in teachers' attitudes toward teaching it. This suggests that it is not a misunderstanding of the theory of evolution that deters teachers from teaching it.

\subsubsection{International Controversy}

The controversy does not exist only in the U.S.. In October, 2006, Poland's deputy education minister called the theory of evolution a lie that has been legalized as common truth (Graebsch, 2006). Maciej Giertych, a PhD in tree physiology, lobbied for obligatory inclusion of creationism in Polish biology curricula. The Polish Academy of Sciences formally protested against this campaign in an open letter in Polish newspapers.

Also in 2006, the Inter-Academy Panel on International Issues published a statement endorsed by 67 member countries urging "decision makers, teachers, and parents to educate all children about the methods and discoveries of science and to foster an understanding of the science of nature" (IAP statement on the teaching of evolution, 2006). This statement was issued in response to public education systems around the world refusing to teach evolution. The statement includes a list of evidence-based facts that should not be considered controversial, including the age of the earth and the process of evolution. It then defines science as focusing on "(i) observing the natural world and (ii) formulating testable and refutable hypotheses to derive deeper explanations for observable phenomena” (p.94).

Chinsamy and Plaganyi (2008) studied the effectiveness of a college evolution course in South Africa to see how residents of a developing nation would be affected. At the time, evolution was not even included in the primary and secondary school curriculum. For factual questions, $18 \%$ of students who did not know if facts were true before the course were able to correctly identify them as true after the course. For religion-based questions, there was almost no change, and major evolutionary concepts also saw almost no change. They concluded that it is much easier to understand and accept isolated facts than complicated scientific concepts such as the overarching theory of evolution.

\subsection{Evolution in the Schools}

\subsubsection{Framework for K-12 Science Education}

A Framework for K-12 Science Education (National Research Council, 2012) lists biological evolution as one of four core ideas in life sciences that all students should know. The Framework also states, "Evolution and its underlying genetic mechanisms of inheritance and variability are key to understanding both the unity and the diversity of life on Earth" (p. 141). The component ideas included in this core concept are:

- Evidence of common ancestry and diversity.

- Natural selection

- Adaptation

- Biodiversity and humans

Creationism and ID are not mentioned in the Framework.

\subsubsection{Methods of Teaching Evolution}

Once it is decided that evolution will be taught in public schools, the next important step is to determine how to cover the subject most effectively. A strategy that has been shown to be effective is teaching about controversy (as opposed to teaching the controversy), where students are given the opportunity to put evolution into a social context, while only teaching the scientific version of evolution (Hildebrand, Bilica, \& Capps, 2008). This strategy has been effectively employed by researchers "in private schools and colleges with the intention of engaging students in an exploration of their personal feelings, thoughts, and beliefs in relationship to the controversy associated with biological evolution" (p.1048). Teaching about controversy has the potential benefit of engaging and motivating students, which may increase the number of students who will remember the lessons later in life. The potential downside is that the lesson could easily turn into a debate in which the teacher ends up teaching the controversy... a violation of the Establishment Clause. It is important to remember when framing these discussions that a concentration on politeness and social discourse within the classroom can be as important as the content discussed (Oliveira, Cook, \& Buck, 2011).

Another effective approach is called proactive, pro-social management, in which the teacher plans with the controversy in mind, but rather than teaching about it, s/he puts a special focus on the qualities of science that make it considered 
science, and does so throughout the year (Hildebrand, Bilica, \& Capps, 2008). This approach is more popular than teaching about the controversy with the National Research Council, the National Science Teachers Association, and other science education groups because it does not bring non-scientific ideas into the science classroom. Students should also be explicitly taught what science is, how to identify it, and why evolution is science and creationism is not (Thanukos, 2010). Thanukos suggests students be given a checklist to determine if what they see in the media counts as science. The goal of this approach is not to demean other ways of knowing, but uses nature of science to draw distinctions between scientific knowledge and other types of knowledge (Hildebrand, Bilica, \& Capps, 2008). That way, when students encounter controversial issues, they are already prepared to understand what constitutes science, and what properly belongs in another discipline such as religion, philosophy, or art.

There are those who argue that the actual topic of evolution must be taught better. Ellis and Wolf (2010) argue that most high school biology textbooks do not define the term "species" before using it regularly in the text, confusing students. Therefore, they conclude that explaining the species concept used by the local curriculum standards early in textbooks would make evolution more accessible to students, because evolution cannot be understood without a clear understanding of what a species is. The molecular biology aspects of evolution are also often left until later, sometimes until college, despite the fact that DNA is where most evolution occurs (Moore, 2008). Gilbert (2003) contends that the secret to teaching evolution well is to do so through the teaching of developmental genetics, because this method is likely to counter the arguments often used by creationists. One scientist even goes so far as to argue that evolution should be taught as being ID, in that, while some processes are random, others are directed by environmental pressures, making it an intelligent process (Costanza, 2009). This, of course, is using a very broad definition of "intelligent."

There are resources in place for teachers to teach evolution, if they know how to use them. In 2009, the United Kingdom's National Centre for Biotechnology Education launched a website entitled "A birthday present from Mr. Darwin," which is free to British schools (Moore, 2008). However, teachers must be taught how to use such resources. In French primary schools, evolution is taught through activities that build up to students working the same way as systematists, biologists who study the relationships between organisms, would study it (Chanet \& Lusignan, 2009). After this sequence, students were found to usually reject the idea of an invisible hand controlling what peppered moths look like as unscientific. In the U.S., project-based evolution units that concentrate on such real-world applications as the development of MRSA have been suggested as the best way to foster interest and understanding (Cook, 2009).

\subsubsection{Avoiding Evolution}

Not all school systems accept the recommendations of the National Science Education Standards, and some even go so far as to look for loopholes in the laws regarding evolution in schools. Some school boards and state legislatures have placed stickers in biology textbooks giving a disclaimer about evolution (Borenstein, 2008). Stickers have been proposed in Alabama, Arkansas, Georgia, Louisiana, and Oklahoma. The purpose of the stickers is to legally express doubt about the theory of evolution in biology classes. The stickers use the word "theory" in the ambiguous manner supported by the creationist movement and imply that the only part of biology that should be examined critically is evolution. Alabama used a sticker from 1996-2001 that was a caution that the textbook includes a discussion of evolution, which is controversial, not well-accepted among scientists, and should be considered as a theory, not a fact. In 2001, the sticker was changed to only say that evolution is controversial. Proponents of these stickers claim they are legal because they have an educational purpose outside of a religious one, but that is the unconstitutional argument used by the Discovery Institute for teaching ID. The argument is that if the stickers do not specifically mention a religious point of view, rather calling into question a non-religious point of view, they should be allowed. So far, every sticker that has gone before a court has been struck down as illegal.

Most states encourage or require the teaching of evolution in public schools. Many parents who do not want their children taught evolution deal with the problem through home-schooling (Apple, 2008). Universities are having problems with students arriving with a deep knowledge and understanding of their parents' version of what constitutes science. These students are at an obvious disadvantage when the time comes to take college biology classes.

\subsection{The Need for a Middle Ground in the Public School Science Curriculum}

Current laws in the U.S. clearly prohibit the teaching of creationism in public school science classrooms. This does not mean that science classrooms should be a place that explicitly teaches students to reject their religious beliefs. If Catholic schools can teach the theory of evolution without contradicting belief in God, then public schools can do so, as well. While there are some religious groups, such as new Earth creationists, that will never be happy if any evolution is taught in public schools, most religious groups do believe in evolution in some form or another. If the discussion moves away from whether or not to teach evolution in public schools to how to teach evolution in public schools, it is possible to write science curricula from a middle ground where worldviews involving science or religion are not mutually exclusive. 


\section{Conclusions}

A middle ground between the theory of evolution and religion must be found to end the controversy that has been a big part of the public discourse for the last century. This middle ground must be found both for foundational beliefs in general and for science curriculum in public schools. The first step, and perhaps the most important step, is for people of all worldviews to recognize the value and legitimacy of others' worldviews. One does not have to agree with other people to recognize their right to their own beliefs, as demonstrated by the granting of freedom of religion by the First Amendment. Many studies have shown psychological benefits to active participation in religion. Green and Elliott (2010) found that religious participation in general is associated with greater health, but fundamentalist religious belief leads to improved happiness over more liberal beliefs. Do most scientists really want to be seen as telling people to give up their religions, because they are not disprovable, even if it means giving up health and happiness? Creationist laypeople may think scientists are asking them to believe in a science they do not completely understand the intricacies of rather than in a religion that the Creationists already believe and have been taught all their lives.

In order for the middle ground to exist, scientists must change the prevailing discourse and make it clear to the lay public that science is not a belief system trying to replace religion. Likewise, religious leaders must make explicit to their followers if evolution does not conflict with the teachings of their religion. If more people like Robert Pollack and Jim Wallis, and religious organizations like the Catholic Church, publicly argue for the benefits of subscribing to both religious and scientific worldviews simultaneously, the conversation can be moved from whether to teach evolution to how to best teach evolution in a way that is compatible with the majority view from both the scientific and religious communities.

In the relative absence of such moderate voices, compared to the more vocal extreme voices, the controversy of whether to teach evolution in public schools does not seem to be ending as quickly as most biologists would wish. However, as other countries have shown us, it is possible to change public opinion by effective teaching of what evolution really means. If moderate scientists and religious leaders take the forefront of the discussion, instead of the vocal minorities on either end of the spectrum, evolution can be taught as science in schools, and creationism can be taught, in whichever form is appropriate for each religion, in places of worship. Many of the religions in the U.S. teach that evolution is acceptable in some form or another, and each religion has a different view of creationism.

Trying to teach creationism alongside evolution in public schools would lead to a situation in which each religious group would have to argue for their version to be the one taught, and it would still belong in a comparative religions class rather than a science class. If creation myths should be taught as science, it could be argued that, in the U.S., the most appropriate creation story to use would be Navajo, Hopi, or Comanche, because their religions were in the U.S. before Judeo-Christian religions.

With so many different opinions of how creationism works, it is unlikely that a compromise that makes everyone happy will ever be reached, unless we separate the teaching of creationism into the various religious institutions. This is not a call for a compartmentalization of individuals' beliefs, but a call for each person to be allowed to learn a set of standard beliefs (evolution) in public schools, and to learn the beliefs of the religion that they choose to follow without having religious beliefs forced upon them.

It is time to acknowledge that science and religion can both serve legitimate functions in human lives, but they are not the same thing and should not be treated as such. Scientists should look to theistic evolutionists as an example to present to policy makers, an example that demonstrates religion and science can coexist within the same belief system. It is this moderate approach to the debate that is most likely to result in a solution where everyone gets what s/he really wants: a quality education for children.

\section{References}

Apple, M. W. (2008). Evolution versus creationism in education. Educational Policy (Los Altos, Calif.), 22(2), 327-335. http://dx.doi.org/10.1177/0895904807312466

Behe, M. (1996). Darwin's black box: The biochemical challenge to evolution. New York: Touchstone.

Borenstein, J. (2008). Textbook stickers: A reasonable response to evolution? Science \& Education, 17(8), 999-1010. http://dx.doi.org/10.1007/s11191-006-9032-z

Center for Science \& Culture. (2011). Intelligentdesign.org. Retrieved March 16, 2011, from http://www.intelligentdesign.org/

Chanet, B., \& Lusignan, F. (2009). Teaching evolution in primary schools: An example in french classrooms. Evolution: Education and Outreach, 2(1), 136-140. http://dx.doi.org/10.1007/s12052-008-0095-y 
Chinsamy, A., \& Plagányi, É. (2008). Accepting evolution. Evolution, 62(1), $248-254$. http://dx.doi.org/10.1111/j.1558-5646.2007.00276.x

Cook, K. (2009). A suggested project-based evolution unit for high school: Teaching content through application. American Biology $\quad$ Teacher, 71(2), 95-98. $\quad$ Retrieved from http://search.ebscohost.com/login.aspx?direct=true\&db=aph\&AN=36619409\&site=ehost-live

Costanza, R. (2009). Evolution is intelligent design. Trends in Ecology \& Evolution, 24(8), 414-415. http://dx.doi.org/10.1016/j.tree.2009.05.001

Dawkins, R. (1996). The blind watchmaker: Why the evidence of evoluiton reveals a universe without design (2nd ed.). New York: W.W. Norton \& Co.

Denton, M. (1985). Evolution: A theory in crisis. Bathesda, MD: Adler \& Adler.

Ellis, M. W., \& Wolf, P. G. (2010). Teaching "species". Evolution: Education and Outreach, 3(1), 89-98. http://dx.doi.org/10.1007/s12052-009-0193-5

Futuyma, D. J. (2009). Evolution (2nd ed.). MA: Sinauer Associates, Inc.

Gilbert, S. F. (2003). Opening darwin's black box: Teaching evolution through developmental genetics. Nature Reviews.Genetics, 4(9), 735-741. http://dx.doi.org/10.1038/nrg1159

Graebsch, A. (2006). Polish scientists fight creationism. Nature (London), 443(7114), 890-891. http://dx.doi.org/10.1038/443890c

Hildebrand, D., Bilica, K., \& Capps, J. (2008). Addressing controversies in science education: A pragmatic approach to evolution education. Science \& Education, 17(8), 1033-1052. http://dx.doi.org/10.1007/s11191-006-9066-2

IAP statement on the teaching of evolution. (2006). Resonance, 11(11), 93-95. http://dx.doi.org/10.1007/BF02834478

Memorandum opinion, 1 (The Middle District of Pennsylvania 2005). Retrieved from http://www.pamd.uscourts.gov/kitzmiller/kitzmiller_342.pdf

Lodge, O. (1925). Evolution. Nature (London), 116(2930), 939-942. http://dx.doi.org/10.1038/116939a0

Matsumura, M. (1998). What do ChristiansReallyBelieve about evolution? Reports of the National Center for Science Education, 18(2), 8-9.

Miller, J. D., Scott, E. C., \& Okamoto, S. (2006). SCIENCE COMMUNICATION: Public acceptance of evolution. Science, 313(5788), 765-766. http://dx.doi.org/10.1126/science.1126746

Moore, A. (2008). Science teaching must evolve. Nature (London), 453(7191), $31-32$. http://dx.doi.org/10.1038/453031a

National Research Council. (2012). A framework for K-12 science education: Practices, crosscutting concepts, and core ideas. Washington, DC: National Academy Press.

Nehm, R. H., \& Schonfeld, I. S. (2007). Does increasing biology teacher knowledge of evolution and the nature of science lead to greater preference for the teaching of evolution in schools? Journal of Science Teacher Education, 18(5), 699-723. http://dx.doi.org/10.1007/s10972-007-9062-7

Oliveira, A. W., Cook, K., \& Buck, G. A. (2011). Framing evolution discussion intellectually. Journal of Research in Science Teaching, 48(3), 257-280. http://dx.doi.org/10.1002/tea.20396

Peters, S. F. (2008a). Edwards v. Aguillard, 482 U.S. 578 (1987). vol. 2. In D. S. Tanenhaus (Ed.), Encyclopedia of the supreme court of the united states (pp. 79-80). Detroit: Macmillan Reference USA.

Peters, S. F. (2008b). Epperson v. Arkansas, 393 U.S. 97 (1968). vol. 2. In D. S. Tanenhaus (Ed.), Encyclopedia of the supreme court of the united states (pp. 122-123). Detroit: Macmillan Reference USA.

Pollack, R. (2005). A place for religion in science? Cross Currents, 55, 252-263,281-282. Retrieved from http://search.proquest.com/docview/214944928?accountid=14585

Radder, R. (2006). On teaching the theory of evolution Springer India, in co-publication with Indian Academy of Sciences. http://dx.doi.org/10.1007/BF02835735

The scopes 'monkey' trial and the separation of church and state, vol. 3: 1920-1929. (2001). In J. S. Baughman (Ed.), American decades. Detroit: Gale.

Scott, E. C. (2004). Evolution vs. creationism: An introduction. Westport, CT: Greenwood Press. 
Smith, S., \& Eve, R. (2009). Texas biology and biological anthropology faculty express their views on teaching evolution. Evolution: Education and Outreach, 2(4), 636-642. http://dx.doi.org/10.1007/s12052-009-0181-9

The ten most harmful books of the 19th and 20th centuries. (2005). Human Events, 61, 6-7. Retrieved from http://search.proquest.com/docview/235854317?accountid=14585

Thanukos, A. (2010). Communicating evolution as science. Evolution: Education and Outreach, 3(2), 254-260. http://dx.doi.org/10.1007/s12052-010-0224-2

Vu, M. A. (2011, June 21, 2011). Francis collins: Atheist richard dawkins admits universe's fine-tuning difficult to explain. The Christian Post

\section{$(\mathrm{cc}) \mathrm{EY}$}

This work is licensed under a Creative Commons Attribution 3.0 License. 